\title{
INFLUENCE OF INITIAL L-ASPARAGINE AND GLYCEROL CONCENTRATIONS ON THE BATCH GROWTH KINETICS OF MYCOBACTERIUM BOVIS BCG
}

\author{
Maria Betania Batista Leal; Júlia Baruque-Ramos*; Haroldo Hiss; Marcelo Fossa da Paz; Maria Cristina Sakai; \\ Umbelina Macedo Vassoler; Luciana Juncioni de Arauz; Isaías Raw \\ Instituto Butantan, Centro de Biotecnologia, São Paulo, SP, Brasil
}

Submitted: December 08, 2003; Returned to Authors: August 23, 2004; Approved: September 27, 2004

\begin{abstract}
The influences of the L-asparagine and glycerol initial concentrations in Sauton medium on the productivities of biomass and colony forming units were studied. The submerged batch cultivations of Mycobacterium bovis were carried out in a $20 \mathrm{~L}$ bioreactor. The L-asparagine and glycerol initial concentrations of $4.54 \mathrm{~g} / \mathrm{L}$ and $25 \mathrm{~mL} / \mathrm{L}$, respectively, corresponded to the best biomass productivity, namely $2.5 \mathrm{~g} / \mathrm{L}$.day. On the other hand, the concentrations of $2.27 \mathrm{~g} / \mathrm{L}$ and $25 \mathrm{~mL} / \mathrm{L}$, respectively, led to the highest productivity in terms of colony forming units, namely $2.7 \cdot 10^{6}$ colonies/mg.day. In addition, by means of the relative consumption analysis of L-asparagine and glycerol (50 and 26\% respectively), it was concluded that the concentrations of such components could be reduced, with respect to the original Sauton medium composition, aiming the obtainment of an optimal BCG vaccine production in the bioreactor.
\end{abstract}

Key words: BCG, Mycobacterium bovis, culture medium, vaccine, submerged batch cultivation

\section{INTRODUCTION}

The tubercle bacillus (Mycobacterium tuberculosis) can grow in almost all human tissues, such as bones, joints and genito-urinary tract. However, the majority of infections of the human variety involve problems, often exclusively in the lungs (1).

After a period of decreased disease cases, from the end of the Second World War to the end of the 70s, one can observe an alarming increase of new tuberculosis cases. In the last decade, 1990-1999, 88 million new cases of tuberculosis were estimated in the world (among them 8 million attributed to infection by the HIV) (2).

Calmette and Guérin, assuming that the acquired immunity depends upon the persistence of living bacilli in the body, developed a vaccine against tuberculosis from a virulent strain of Mycobacterium bovis (isolated from milk) after 230 passages on a glycerol-bile-potato medium for a period of 13 years (from 1908 to 1920). After that period, the strain became avirulent and hence was called BCG (Bacille Calmette-Guérin) (1). Besides its action as a vaccine against tuberculosis, the $\mathrm{BCG}$ has proved to be a non-specific stimulant of immune systems and it is one of the clinic immunotherapic forms approved for the treatment against superficial cancer of the bladder in the United States (3).

In Brazil, the sub-strain BCG-Moreau, received by Arlindo de Assis in 1927 from the Pasteur Institute in Paris (4), was initially used. Later, the sub-strain Copenhagen, currently used in the production at Instituto Butantan, was used. In this production process, which has continued until the present, the BCG is cultivated in glass flasks on a shallow layer of nonstirred Sauton medium (static cultivation) (5). The microorganism grows as a coherent pellicle on the liquid medium surface. After a pressing of the bacterial pellicle in a Birkhaug apparatus to a damp cake (containing approximately $20 \%$ dry weight of cells), a suspension is prepared in a $2 \%$ sodium glutamate solution by shaking the cake in the presence of steel balls. This procedure causes a destruction of 40 to $60 \%$ of the cells with a consequent decrease in the vaccine efficiency (6).

*Corresponding author. Mailing address: Instituto Butantan, Centro de Biotecnologia. Av. Dr. Vital Brazil, 1500, Butantã. 05503-900, São Paulo, SP, Brasil. Tel.: (+5511) 3726-7222, Ext. 2182. Fax: (+5511) 3726-1505. E-mail: jbaruque@ butantan.gov.br 
The purpose of this work is to study the production of the $\mathrm{BCG}$ vaccine in dispersed cultivation in the bioreactor (avoiding thus the further bacillary dispersion with steel balls). From this, a desirable increase of the viable cells follows, in comparison to the static cultivation. As described by Gheorghiu (7), the submerged cultivation also produces bacteria which are more resistant to the freeze-drying process and storage at room temperature than the bacteria produced by static cultivation. More specifically, the purpose of this work is to study the influence of the initial L-asparagine and glycerol concentrations in Sauton medium on growth, in order to adapt the composition of this medium for the submerged batch cultivation.

\section{MATERIALS AND METHODS}

\section{Microorganism}

For the preliminary runs, carried out in shaken flasks, ampoules of BCG were employed as inoculum (Moreau strain from Copenhagen - secondary seed lot), each containing $5 \mathrm{mg}$ of the lyophilized microorganism dated July 1978.
For the runs in bioreactor, ampoules from the Production Laboratory of the Instituto Butantan were used (lyophilized lot 3/95 BCG ID).

\section{Culture medium}

The Sauton medium was used (5) for the inoculum and bioreactor cultivations with the following composition: Lasparagine, $4.54 \mathrm{~g} / \mathrm{L}$; citric acid, $2.0 \mathrm{~g} / \mathrm{L} ; \mathrm{K}_{2} \mathrm{HPO}_{4}, 0.5 \mathrm{~g} / \mathrm{L}$; $\mathrm{MgSO}_{4} .7 \mathrm{H}_{2} \mathrm{O}, 1.0 \mathrm{~g} / \mathrm{L}$; ferriammonium citrate, $0.05 \mathrm{~g} / \mathrm{L}$; glycerol, $60.0 \mathrm{~mL} / \mathrm{L}(\mathrm{v} / \mathrm{v})$. The $\mathrm{pH}$ was adjusted to 7.2 with a $4 \mathrm{~N} \mathrm{NaOH}$ solution.

The cultivation media were sterilized by filtration through a $0.2 \mu \mathrm{m}$ membrane for preliminary experiments 1 to 4 . For the assays carried out in the bioreactor ( 5 to 13 ) the cultivation media were sterilized inside the vessel at $121^{\circ} \mathrm{C}$ for $30 \mathrm{~min}$. Besides the fact that the sterilization by wet heat is easier than filtration, it was verified that heating the medium did not cause alterations in the growth kinetics (8).

The modifications of the initial L-asparagine and glycerol concentrations with respect to the original Sauton medium composition are expressed in Table 1.

Table 1. Factorial planning design and result analysis for preliminary experiments 1 to 4 carried out in shaker.

\begin{tabular}{|c|c|c|c|c|c|c|c|c|c|}
\hline \multicolumn{10}{|c|}{$\begin{array}{l}\text { (X1) Tween-80 (v/v): } 0(-) / 0.025 \%(+) \\
\left(\text { X2) Glycerol }(\mathrm{mL} / \mathrm{L}): 25(-) / 60(+)^{1}\right. \\
\left(\text { X3) L-asparagine.H2O (g/L): } 2.27(-) / 4.54(+)^{1}\right.\end{array}$} \\
\hline \multirow{2}{*}{$\begin{array}{l}\text { Erlenmeyer } \\
\text { Number }\end{array}$} & \multirow{2}{*}{$\begin{array}{c}\text { Average } \\
\text { Calculation }\end{array}$} & \multicolumn{3}{|c|}{ Factorial Planning of Assays } & \multicolumn{4}{|c|}{ Interaction Effects } & \multirow{2}{*}{$\begin{array}{c}\text { Dry } \\
\text { Biomass }^{2}\end{array}$} \\
\hline & & (X1) & $(\mathrm{X} 2)$ & (X3) & $\mathrm{X} 1 \mathrm{X} 2$ & $\mathrm{X} 1 \mathrm{X} 3$ & $\mathrm{X} 2 \mathrm{X} 3$ & $\mathrm{X} 1 \mathrm{X} 2 \mathrm{X} 3$ & \\
\hline 1 & + & + & + & + & + & + & + & + & $\mathbf{0}$ \\
\hline 2 & + & + & + & - & + & - & - & - & $\mathbf{0}$ \\
\hline 3 & + & + & - & + & - & + & - & - & $\mathbf{0}$ \\
\hline 4 & + & + & - & - & - & - & + & + & $\mathbf{0}$ \\
\hline 5 & + & - & + & + & - & - & + & - & 4.59 \\
\hline 6 & + & - & + & - & - & + & - & + & 3.38 \\
\hline 7 & + & - & - & + & + & - & - & + & 3.16 \\
\hline 8 & + & - & - & - & + & + & + & - & 2.76 \\
\hline Divisor & 8 & 4 & 4 & 4 & 4 & 4 & 4 & 4 & $\longrightarrow$ \\
\hline \multicolumn{2}{|l|}{ Average $=$} & \multicolumn{2}{|c|}{$1.74 \pm 0.25$} & & & & & & \\
\hline \multicolumn{2}{|c|}{ Effect of $(X 1)=$} & \multicolumn{2}{|c|}{$-3.48 \pm 0.51$} & & & & & & \\
\hline \multicolumn{2}{|c|}{ Effect of $(X 2)=$} & \multicolumn{2}{|c|}{$0.51 \pm 0,51$} & & & & & & \\
\hline \multicolumn{2}{|c|}{ Effect of $(X 3)=$} & \multicolumn{2}{|c|}{$0.40 \pm 0.51$} & & & & & & \\
\hline \multicolumn{2}{|c|}{ Interaction Effect $(\mathrm{X} 1 \mathrm{X} 2)=$} & \multicolumn{2}{|c|}{$-0.51 \pm 0.51$} & & & & & & \\
\hline \multicolumn{2}{|c|}{ Interaction Effect $(\mathrm{X} 1 \mathrm{X} 3)=$} & \multicolumn{2}{|c|}{$0.40 \pm 0.51$} & & & & & & \\
\hline \multicolumn{2}{|c|}{ Interaction Effect $(\mathrm{X} 2 \mathrm{X} 3)=$} & \multicolumn{2}{|c|}{$-0.20 \pm 0.51$} & & & & & & \\
\hline \multicolumn{2}{|c|}{ Interaction Effect $(\mathrm{X} 1 \mathrm{X} 2 \mathrm{X} 3)=$} & \multicolumn{2}{|c|}{$-0.20 \pm 0.51$} & & & & & & \\
\hline
\end{tabular}

${ }^{1}$ Original concentrations in Sauton medium: $60 \mathrm{~mL} / \mathrm{L}$ and $4.54 \mathrm{~g} / \mathrm{L}$ of glycerol and L-asparagine respectively;

${ }^{2}$ Average of experiments 1 to 4 . Expressed in total dry biomass per erlenmeyer contents (g). 


\section{Preparation of inoculum}

In a $300 \mathrm{~mL}$ erlenmeyer flask, $100 \mathrm{~mL}$ of Sauton medium were inoculated with the contents of one ampoule. The flask was agitated on a rotatory shaker at $198 \mathrm{~min}^{-1}, 37^{\circ} \mathrm{C}$, for 13 days. This culture was used as inoculum for the preliminary runs in shaken flasks and the same procedure was adopted for the inoculation of the bioreactor.

\section{Cultivation conditions}

\section{Preliminary cultivation runs}

Eight cultivation runs were carried out according to the factorial planning design $2^{3}$ (9) (see Table 1), repeated four times (assays 1 to 4), each one in shaken flasks of $300 \mathrm{~mL}$ of capacity with $100 \mathrm{~mL}$ of Sauton medium, agitated at $198 \mathrm{~min}^{-1}$ and temperature controlled at $37 \pm 0.5^{\circ} \mathrm{C}$. The values adopted for the initial concentrations of L-asparagine, glycerol and Tween 80 in the Sauton medium are also listed in Table 1. The Tween 80 was used as a dispersing agent.

The analysis of the influence indicated in Table 1 was based on the dry biomasses formed in each flask contents after 13 days of cultivation.

\section{Cultivation runs in bioreactor}

The experiments were carried out in a $20 \mathrm{~L}$ bioreactor (LSL Biolafitte S.A., Saint Germain en Laye, France) constituted of a stirred cylindrical vessel of borosilicate glass with a half spherical bottom ( $23 \mathrm{~cm}$ diameter) and a top-driven agitator. A marine propeller promoted the agitation with six blades set at a $45^{\circ}$ angle. This propeller was located $15 \mathrm{~cm}$ from the vessel bottom and the aeration was done at the surface medium into the vortex formed by the absence of baffles. The initial medium volume was near $12 \mathrm{~L}$, the aeration rate corresponded to $15 \mathrm{~L} /$ min, the cultivation temperature was $37^{\circ} \mathrm{C}$ and the manometric head vessel pressure was $4 \mathrm{~cm} \mathrm{Hg}$. The agitation frequency was $1200 \mathrm{~min}^{-1}$ for experiment 5 only and $840 \mathrm{~min}^{-1}$ for all other experiments. The initial $\mathrm{pH}$ of the Sauton medium was previously adjusted to 7.2 with a $4 \mathrm{~N} \mathrm{NaOH}$ solution.

The initial adopted concentrations of L-asparagine and glycerol were equal to those of the preliminary experiments and a factorial planning design $2^{2}$ was done as shown in Table 2.

\section{Analytical methods}

Cell Concentration. Expressed as dry biomass, determined by filtration of a sample in quantitative paper, followed by the pellet drying at $60^{\circ} \mathrm{C}$ for $48 \mathrm{~h}$. The obtained cell concentration value, multiplied by the medium volume, was transformed into total dry biomass $\left(\mathrm{M}_{\mathrm{x}}\right)$ in order to exclude the medium evaporation effect on the mentioned concentration (10).

Glycerol Concentration. The method used (11) was based on the glycerol oxidation by sodium periodate, in which glycerol reacts with sodium periodate in acid solution generating aldehyde and formic acid. The formic acid was titrated with a $\mathrm{NaOH}$ solution $(0.125 \mathrm{~N})$ and the volume spent corresponded

Table 2. Factorial planning design and result analysis for experiments 5 to 6 carried out in bioreactor.

(X2) Glycerol (mL/L): $25(-) / 60$ (+)

(X3) L-asparagine. $\mathrm{H}_{2} \mathrm{O}(\mathrm{g} / \mathrm{L}): 2.27(-) / 4.54(+)$

\begin{tabular}{|c|c|c|c|c|c|c|c|c|c|}
\hline $\begin{array}{l}\text { Assay } \\
\text { Number }\end{array}$ & $\mathrm{X} 2$ & $\mathrm{X} 3$ & $\mathrm{X} 2 \mathrm{X} 3$ & $\begin{array}{c}\text { Agitation } \\
\text { Frequency } \\
\left(\min ^{-1}\right)\end{array}$ & $\begin{array}{c}\mu_{\max } \\
\left(\text { day }^{-1}\right)\end{array}$ & $\begin{array}{c}\mathrm{P}_{\mathrm{CFU}} \cdot 10^{-6} \\
\text { (CFU/mg.day) }\end{array}$ & $\begin{array}{c}\mathrm{P}_{\mathrm{Mx}} \\
\text { (g/day) }\end{array}$ & $\begin{array}{c}\text { L-asparagine } \\
\text { consumption } \\
(\%)\end{array}$ & $\begin{array}{c}\text { Glycerol } \\
\text { consumption } \\
(\%)\end{array}$ \\
\hline 5 & + & + & + & 1200 & 0.08 & $\longrightarrow$ & 0.16 & 20.3 & 19.6 \\
\hline 6 & + & + & + & 840 & 0.44 & - & 2.25 & 30.5 & 23.0 \\
\hline 7 & + & + & + & 840 & 0.24 & 1.68 & 1.83 & 41.1 & 27.7 \\
\hline 8 & - & + & - & 840 & 0.38 & 1.21 & $2.47^{2}$ & 38.6 & 33.3 \\
\hline 9 & - & + & - & 840 & 0.41 & 0.25 & $2.53^{2}$ & 34.7 & 30.8 \\
\hline 10 & + & - & - & 840 & 0.33 & 1.42 & 2.41 & 42.1 & 25.0 \\
\hline 11 & + & - & - & 840 & 0.40 & $\longrightarrow$ & 2.16 & 32.5 & 16.2 \\
\hline 12 & - & - & + & 840 & 0.33 & $2.01^{1}$ & 2.24 & $49.6^{3}$ & $21.3^{4}$ \\
\hline 13 & - & - & + & 840 & 0.30 & $3.35^{1}$ & 2.17 & $51.1^{3}$ & $30.7^{4}$ \\
\hline
\end{tabular}

${ }^{1}$ Maximum average for $\mathrm{P}_{\mathrm{CFU}}=2.68 .10^{6} \mathrm{UFC} / \mathrm{mg}$.day;

${ }^{2}$ Maximum average for $\mathrm{P}_{\mathrm{Mx}}=2.50 \mathrm{~g} / \mathrm{day}$;

${ }^{3}$ Maximum average for L-asparagine consumption $=50 \%$;

${ }^{4}$ Maximum average for glycerol consumption $=26 \%$. 
to the glycerol concentration. This result multiplied by the medium volume was transformed into total mass of glycerol $\left(\mathrm{M}_{\mathrm{G}}\right)$.

Supernatant Total Nitrogen Concentration. Estimated using the Semi-Micro Kjeldahl method (12) through digestion with sulfuric acid and copper sulfate as catalyst for 4 hours. The ammonium sulfate formed was distilled in the presence of $\mathrm{NaOH}$ $10 \mathrm{~N}$ to discharge the ammonia vapor (13), which was absorbed in a boric acid solution in the presence of a mixed indicator followed by titration with a standard solution of $\mathrm{HCl}$. The $\mathrm{HCl}$ expended corresponded to the nitrogen in the sample, according to the equation:

$$
\text { Nit.(g/L) }=\frac{1.401 \cdot 10^{7} \cdot \mathrm{V} . \mathrm{N}}{\mathrm{Al}}
$$

where,

$\mathrm{V}=\mathrm{HCl}$ expended volume $(\mathrm{mL})$;

$\mathrm{N}=\mathrm{HCl}$ normality;

$\mathrm{A} 1$ = sample volume $(\mathrm{mL})$.

This value, multiplied by the medium volume, was transformed in total supernatant nitrogen mass $\left(\mathrm{M}_{\mathrm{N}}\right)$.

Colony Forming Units (CFU). Determined by a counting of the colonies grown in Loewenstein-Jensen agar-medium (4) at $37^{\circ} \mathrm{C}$ for 28 days, of a sample previously diluted (1:4) with sterilized Sauton medium. The calculation was based on the statistic method recommended by the OMS (14).

Percentage of Dissolved Oxygen. Determined by an on-line polarographic probe (Ingold model Oxygraf 400) installed and sterilized together with the vessel. The saturation point (100\%) was calibrated before the inoculation, under the same cultivation conditions $\left(37^{\circ} \mathrm{C}, 4 \mathrm{~cm} \mathrm{Hg}\right.$ head vessel pressure, agitation as the cultivation condition).

Sterility Test. This control was done through the inoculation of $0.5 \mathrm{~mL}$ of the sample in a test tube containing Brewer medium (4), maintained at $37^{\circ} \mathrm{C}$ (for bacteria presence detection), and in another tube with casein soya broth (15) maintained at room temperature (for fungi detection). The tubes were inoculated for a period of one week or more.

Two staining methods: one, the Ziehl-Neelsen (4) for microscopic mycobacteria detection and the other, the Gram test (4) for eventual observation of contaminants, were also employed.

Maximum specific growth rate $\left(\mu_{\max }\right)$. It was calculated according to the following equations for the exponential phase:

$$
\begin{aligned}
& \log \left(M_{x}\right)=a \cdot\left(t-t_{i}\right)+b \\
& \ln \left(M_{x}\right)=2.303 \cdot a \cdot\left(t-t_{i}\right)+2.303 \cdot b \\
& \mu_{\max }=2.303 \cdot a=\left(1 / M_{x}\right) \cdot\left(d M_{x} / d t\right)
\end{aligned}
$$

where,

$\mathrm{M}_{\mathrm{x}}(\mathrm{g})$ has the same meaning as defined in analytical methods at the cultivation time " $t$ " (day);

"a" is defined by equation 4 ;

"b" represents the log of biomass $\mathrm{M}_{\mathrm{xi}}$ at beginning of exponential phase $t_{i}$.

Dry biomass productivity $\left(\mathbf{P}_{\mathrm{Mx}}\right)$. The time of the exponential growth phase end was taken to calculate the dry biomass productivity:

$$
\mathrm{P}_{\mathrm{Mx}}=\frac{\left(\mathrm{M}_{\mathrm{Xc}}-\mathrm{P}_{\mathrm{Xi}}\right)}{\left(\mathrm{T}_{\mathrm{c}}-\mathrm{t}_{\mathrm{i}}\right)}
$$

where,

$\mathrm{M}_{\mathrm{Xc}}$ - total dry biomass at the exponential growth phase end $(\mathrm{g})$;

$\mathrm{T}_{\mathrm{c}}$ - time of the exponential growth phase end (day).

CFU productivity $\left(\mathbf{P}_{\mathrm{CFU}}\right)$. The minimum values observed of dissolved oxygen, during the process of cultivation coincided with the maximum values of CFU. In this way, this productivity was calculated in a similar way of equation (5):

$$
\mathrm{P}_{\mathrm{CFU}}=\frac{\left(\mathrm{CFU}_{\mathrm{m}}-\mathrm{CFU}_{\mathrm{i}}\right)}{\left(\mathrm{t}_{\mathrm{O}_{2} \min }-\mathrm{t}_{\mathrm{i}}\right)}
$$

where,
$\mathrm{CFU}_{\mathrm{m}}$ - maximum value of colony forming units, corresponding to the minimum dissolved oxygen in the medium, obtained after a semi-logarithmic fit between CFU and fermentation time (colonies/mg).
$\mathrm{CFU}_{\mathrm{i}}$ - value of colony forming units at the beginning of the exponential growth phase (colonies/mg);
$\mathrm{t}_{\mathrm{O} 2 \mathrm{~min}}$ - cultivation time corresponding to the minimum value of dissolved oxygen in cultivation medium (day).

\section{RESULTS}

\section{Analysis of the effects in the factorial planning of the preliminary assays}

The calculated effects and their interactions are presented in Table 1. Considering that the highest negative effect is caused by $\mathrm{X} 1$, the conclusion is that the Tween- 80 exerts an inhibitory effect on the cellular growth at an initial concentration of $0.025 \%(\mathrm{v} / \mathrm{v})$. 
Studies carried out by Sakai (8) show that such effect depends on the relation: Tween-80 concentration / cellular concentration.

As for the L-asparagine and glycerol, the effects (X2 and X3) are positive for the highest concentrations of these components (Table 1: 4.54 and $60 \mathrm{~mL} / \mathrm{L}$ respectively). Their differences, however, are not significantly high.

These preliminary conclusions have, therefore, allowed for the planning of assays 5 to 13, carried out in submerged cultivations in the bioreactor. In these experiments no Tween80 was added, but the levels of concentration for L-asparagine and glycerol were maintained.

\section{Analysis of results obtained in experiments carried out in bioreactor}

The results are shown in Figs. 1 to 3 and Table 2.

A similar cellular growth behavior was observed in all experiments, as it can be seen by comparing the growth curves. The exception was cultivation run 5 (Fig. 1) with a near absence of growth. In the same way, comparing the values of productivity $\left(\mathrm{P}_{\mathrm{Mx}}\right)$ and maximum specific growth rate $\left(\mu_{\max }\right)$, shown in Table 2 , they are lower for run 5 than for the other assays. The agitator frequency of $1200 \mathrm{~min}^{-1}$ in run 5 , higher than in the other experiments $\left(840 \mathrm{~min}^{-1}\right)$, explains such differences since vigorous mixing provokes mechanical stress, which is detrimental to growth (1).

The CFU productivity was based on the minimum dissolved oxygen value $\left(\mathrm{P}_{\mathrm{CFU}}\right)$ because at this point it was the maximum viable count $(8,16,17)$. Such behavior was also confirmed in this work, as it can be seen in figure 4: the maximum value of CFU

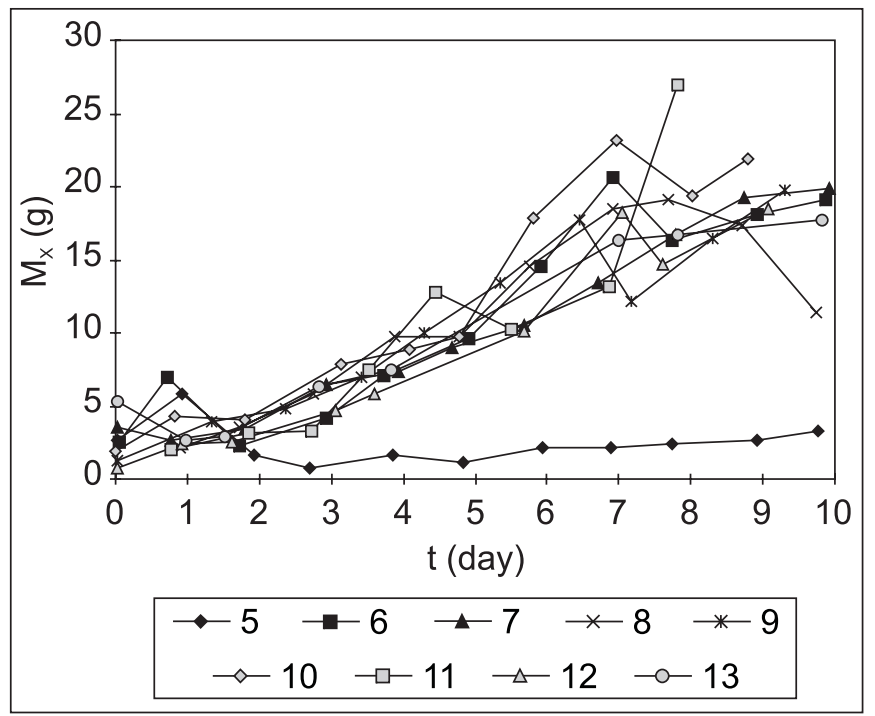

Figure 1. Total dry biomass $\left(\mathrm{M}_{\mathrm{x}}\right)$ obtained by the multiplication of the cell concentration value and the medium volume for experiments in bioreactors 5 to 13 .

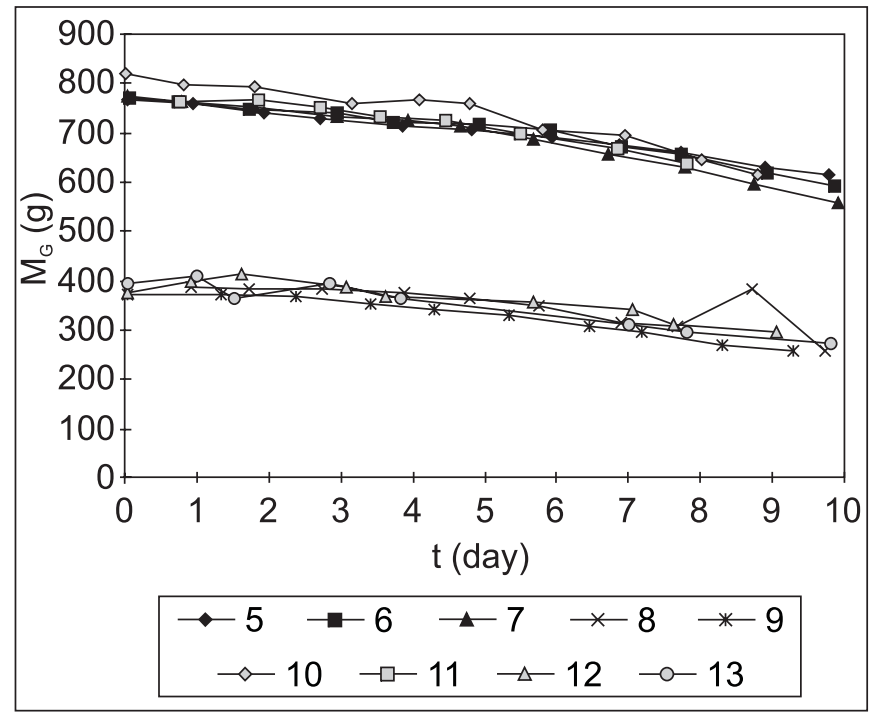

Figure 2. Total glycerol mass $\left(\mathrm{M}_{\mathrm{G}}\right)$ obtained by the multiplication of the glycerol concentration value and the medium volume for experiments in bioreactors 5 to 13 .

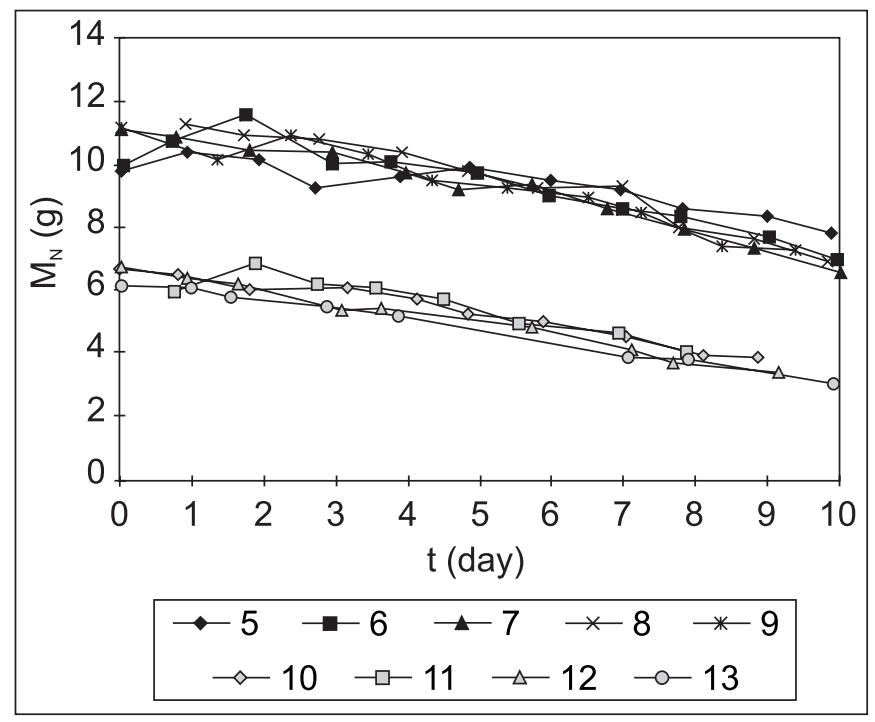

Figure 3. Total supernatant nitrogen mass $\left(\mathrm{M}_{N}\right)$ obtained by the multiplication of the nitrogen concentration value and the medium volume for experiments in bioreactors 5 to 13 .

corresponds to the minimum value of oxygen concentration in the medium since the population of viables is responsible for the oxygen uptake. In addition, once a relationship between the number of living bacilli and the immunogenic potency was verified (18), the maximum value of colony forming units $\left(\mathrm{CFU}_{\mathrm{m}}\right)$ is important for the calculation of the related productivity, which, 


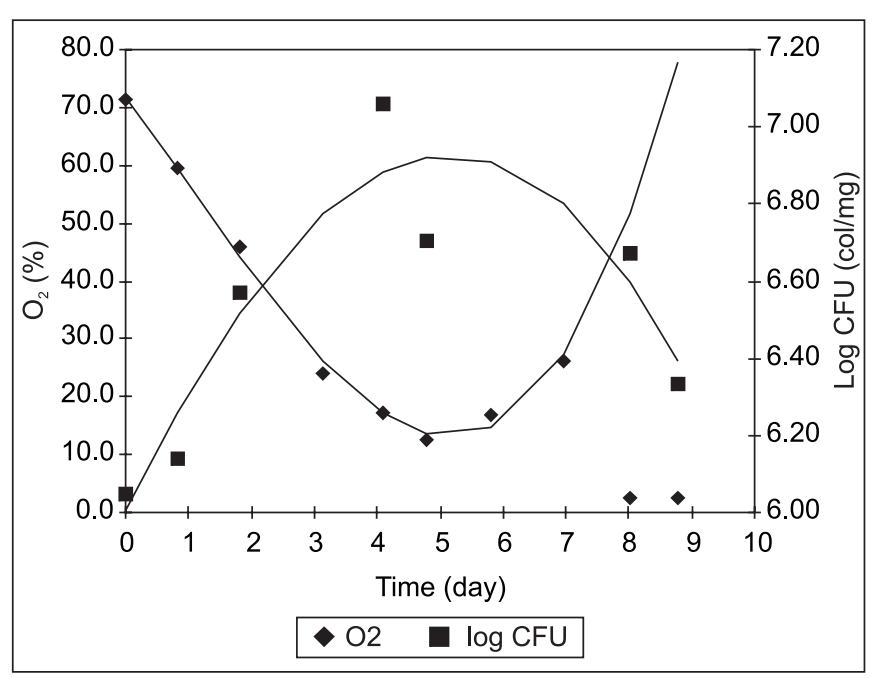

Figure 4. Dissolved oxygen in the medium $\left(\mathrm{O}_{2}\right)$ and colony forming units (CFU) as a function of cultivation time.

therefore, corresponds to the cultivation harvest time and consequently to a highly immunogenic BCG.

The results in Table 2 show that the lowest initial glycerol and the highest L-asparagine concentrations implied the maximum dry biomass productivity (runs 8 and $9, \mathrm{P}_{\mathrm{Mx}}=2.50 \mathrm{~g} /$ day), but not the maximum CFU productivity (runs 12 and 13, $\mathrm{P}_{\mathrm{CFU}}=2.68 \cdot 10^{6} \mathrm{CFU} / \mathrm{mg}$.day).

Moreover, concerning relative consumption of substrates, shown in figures 1 to 3, it is possible to estimate the averages of global yield factors $\left(\mathrm{Y}_{\mathrm{X} / \mathrm{G}}=0.14\right.$ and $\mathrm{Y}_{\mathrm{X} / \mathrm{N}}=5.25$ respectively), which led to an average relation (carbon/nitrogen) namely $\mathrm{C} / \mathrm{N}$ $\cong 16(\mathrm{w} / \mathrm{w})$. The maximum variation coefficient for these calculated averages was $30.0 \%$.

\section{DISCUSSION}

This microorganism generally grows as a surface veil in nonagitated culture flasks. In Instituto Butantan, the BCG lyophilized vaccine is supplied in vials with 10 doses, containing $1 \mathrm{mg}$ of BCG lyophilized and between 2 to 10 million of live bacilli each. The production is 70,000 vials or 700,000 doses. For this purpose, $96 \mathrm{~L}$ of Sauton medium are prepared weekly and distributed in aliquots of $80 \mathrm{~mL}$ (in flasks of $300 \mathrm{~mL}$ ), totaling 1,200 flasks for the static cultivation of Mycobacterium bovis BCG (19). This represents an approximated concentration of $0.7 \mathrm{~g}$ of bacteria per liter of medium. In the present work higher values of dry biomass productivity and CFU productivity are obtained (Table 2 ). These data are truly promising regarding process transposition from static to submerged cultivation in bioreactors.

The increase of the BCG production is a public necessity considering it is the most widely used vaccine in the world against tuberculosis. Besides this, it is a useful vaccine for delivering protective antigens of multiple pathogens (20). Since the early 90's the BCG has been studied for this purpose because of its unique characteristics, including low toxicity adjuvant potential and long-lasting immunity (21). These recombinant BCG strains can elicit long-lasting humoral and cellular immune responses to foreign antigens (22). Several studies were done with this approach for developing vaccines against diverse diseases: AIDS (23), hepatitis C (24), leishmaniosis (25) and several others. In accordance with this approach, Instituto Butantan recently developed a recombinant Mycobacterium bovis BCG expressing the Sm14 antigen of Schistosoma mansoni which protected mice submitted to cercarial challenge tests (26). Also, it is remarkable that in Instituto Butantan there is another research line studying the use of recombinant proteins for developing a vaccine against tuberculosis which is more potent than the classical one (27).

However, very little data are found in the literature related to suitable BCG process production in bioreactors. A suitable small scale cultivation in the bioreactor has been recently described (28). It was performed in a $3 \mathrm{~L}$ total capacity vessel, employing 2 L of Sauton medium, at a cultivation temperature of $37^{\circ} \mathrm{C}$, dissolved oxygen controlled above $20 \%$ saturation and agitation frequency varying from 360 to $500 \mathrm{rpm}$. The microorganism was M. bovis BCG (Copenhagen strain) cultivated for $164 \mathrm{hs}$ ( 6 days and $20 \mathrm{~h}$ ). The maximum cell concentration achieved was equivalent to an optical density (measured at $600 \mathrm{~nm}$ ) of 2.2 units and a CFU value of $1.02 \cdot 10^{9} / \mathrm{mL}$. According to that report, the bioreactorgrown BCG bacteria exhibited a similar vaccine efficacy against a challenge (in tests with mice) with $M$. tuberculosis with regard to the BCG obtained from the classical surface-grown culture. Thus, through those biological tests, the real possibility of process transposition from static to submerged cultivation in bioreactors was proven. However, still considering the great importance of the information contained in that paper, their focus was not on showing a clear growth curve, neither a clear dissolved oxygen variation in the medium. Furthermore, a kinetic study of carbon and nitrogen source consumptions was not presented.

For scale-up bioreactor cultivations, besides the c-GMP norms, which recommend the use of chemically, defined medium (29), the use of an optimized cultivation medium is advisable for economic reasons. Thus, the present study describes, in a larger scale, the preliminary kinetic analysis in order to contribute to the search of such optimization.

In the present work, slow bacterial growth (average of $\mu_{\max }$ $=0.35$ day $^{-1}$ - runs 6 to 13 ) was observed, even in the bioreactor (Fig. 1) where the agitation is very efficient. The slow growth of many mycobacteria is probably due to the hydrophobic character of the cellular wall surface, which makes the transport of the nutrients through the bacterial cell membrane difficult (30). On the other hand, being the high lipid content a characteristic of the mycobacteria (constituting $60 \%$ of the cellular wall), the addition of glycerol and lipids to the cultivation 
medium favors cellular growth (4), thus justifying the use of glycerol in the cultivation medium. This specific necessity of carbon source related to the high bacterial lipid content was also evident in the high relation carbon/nitrogen as assessed in the batch cultivations (see previous section).

In addition, there is a need for high initial concentrations of the medium components in static cultures because the transport of nutrients to the microorganism/medium interface occurs by molecular diffusion, which in turn depends on the concentration gradients. On the other hand, in the submerged culture with constant stirring, such high concentration values are not necessary because continuous mixing facilitates the transport. An excessive presence of certain medium components may cause the inhibition of bacterial growth. The results in Table 1 show this effect on the final dry biomass production.

The detergent Tween- 80 exerts an evident inhibitory effect on the cellular growth at concentration of $0.025 \%$ (v/v) as demonstrated in the result analysis (Table 1). For this reason, the Tween- 80 was not used in bioreactor cultivations. However, it must be considered that this detergent exerts two distinct and antagonistic effects: it stimulates bacterial growth by allowing higher access of the microorganisms to the nutrients through reduction of the bacterial clump size and consequent increase of the specific area; on the other hand, it inhibits bacterial growth, probably through the oleic acid action, which is toxic for the bacilli. The inhibition depends on the relation between the concentrations of Tween-80 and the cells (8). Curiously, in the paper cited previously (28), the authors affirm that in their process conditions the optimal dissociation of the bacilli was achieved at $0.3 \%$ Tween-80. This value is greater than that employed in the preliminary assays carried out in flasks. Thus, although its use was discarded in bioreactor cultivations in the present work, these apparently contradictory data lead to the supposition that the Tween- 80 concentration must be optimized in future studies according to the process conditions adopted.

The results in Table 2 show that the lowest initial glycerol and the highest L-asparagine concentrations implied the maximum dry biomass productivity ( $\mathrm{P}_{\mathrm{Mx}}=2.50 \mathrm{~g} /$ day $)$, but not the maximum CFU productivity. The condition above could be recommended for purified protein derivative (PPD) production, which is associated to biomass production. If, however, the vaccine production is the aim, where its efficiency depends on the number of viable units, the condition of lowest initial concentrations of L-asparagine and glycerol possibly represents the recommended composition of the cultivation medium $\left(\mathrm{P}_{\mathrm{CFU}}=2.68 \cdot 10^{6} \mathrm{CFU} /\right.$ mg.day). Of course that appropriate product tests must be still carried out to confirm or not the considerations above.

Figs. 2 and 3 show incomplete consumptions of glycerol and nitrogen, considering that residual values of $\mathrm{M}_{\mathrm{G}}$ and $\mathrm{M}_{\mathrm{N}}$ were present after 10 days of cultivation. Based on the lowest level of initial glycerol concentration (Table 2), the relative consumptions of $\mathrm{M}_{\mathrm{N}}$ for pairs of experiments 12, 13 and 8, 9, corresponded to $50 \%$ and $36.7 \%$ respectively. For the highest level of this substance (pairs of assays 6, 7 and 10,11) the inhibitory effect of L-asparagine was not disclosed, taking into account that the relative consumption of this last substrate practically did not vary (36.0 and $37.3 \%$ respectively).

Thus, as already described above, considering the best value of productivity in $\mathrm{CFU}\left(\mathrm{P}_{\mathrm{CFU}}=2.68 \cdot 10^{6} \mathrm{CFU} / \mathrm{mg}\right.$.day $)$ and the presence of $\mathrm{L}$-asparagine and glycerol in their lowest initial concentrations (assays 12 and 13), where the average consumed is nearly 50 and $26 \%$ respectively, one concludes that the reduction of concentrations of these substrates in relation to the original Sauton medium composition leads to the improvement of productivity in CFU. This way, if one takes the possibility to reduce the initial levels of these two components even more as a starting point, future studies will be carried out in order to optimize the Sauton medium, aiming at an adequate $\mathrm{BCG}$ vaccine production in the bioreactor.

\section{ACKNOWLEDGMENTS}

Financial support from Fundação Butantan is gratefully acknowledged. We would like to thank CAPES and FUNDAP for the research studentships. The authors would also like to thank Mr. Lourivaldo Inácio de Souza, Mr. Máximo de Moraes, Mr. Hélio Fernandes Chagas, Ms. Inês do Amaral Maurelli, Ms. Salete Vargas and Ms. Fátima Aparecida Mendonça de Oliveira for their technical support.

\section{RESUMO}

\section{Influência das concentrações iniciais de asparagina e glicerol sobre a cinética de crescimento submerso de Mycobacterium bovis}

Estudou-se a influência das concentrações iniciais, no meio de Sauton, de asparagina e glicerol sobre as produtividades, expressas em unidades formadoras de colônias e biomassa microbiana, referentes aos cultivos submersos do Mycobacterium bovis, em biorreator de $20 \mathrm{~mL}$. As concentrações iniciais de 2,27 e $25 \mathrm{~mL} / \mathrm{L}$ de asparagina e glicerol, respectivamente, conduziram à maior produtividade, em unidades formadoras de colônias, a saber $2,7.10^{6}$ colônias/mg.dia. Por outro lado, as concentrações de 4,54 e 25 mL/L dos mesmos componentes, corresponderam à melhor produtividade em biomassa, a saber: $2,5 \mathrm{~g} /$ dia. Através das análises dos consumos relativos de asparagina e glicerol (50 e $26 \%$ respectivamente), verificou-se também que as concentrações destes componentes podem ser reduzidas na composição original do meio de Sauton, com o objetivo de obter uma produção otimizada de vacina BCG em bioreator.

Palavras-chave: BCG, Mycobacterium bovis, meio de cultura, vacina, cultivo submerso descontínuo 


\section{REFERENCES}

1. Hemert, V. Vaccine production as a unit process. In: Progress in Industrial Microbiology. Churchil Livingstone, Edinburgh and London, 1974, v.13, p.227-233.

2. Dolin, P.S.; Raviglione, M.C.; Kochi, A. Global tuberculosis incidence and mortality during 1990-2000. Bull. World Health Org., 72(2):213220, 1994.

3. Groves, M.J. Pharmaceutical characterization of Mycobacterium bovis bacillus Calmette-Guérin (BCG) vaccine used for the treatment of superficial bladder cancer. J. Pharm. Sciences, 82(6):555-562, 1993.

4. Bier, O. Microbiologia e Imunologia. $24^{\text {th }}$ ed. Ed. Melhoramentos, São Paulo, 1985, 1234p.

5. Cassagne, H. Millieux de Culture. In: Collection "Techniques de Base”. Tome 2. Éditions de la Tourelle Saint-Mandé, Paris, 1961, p. 242 .

6. Kim, T.H. High-viability lyophilized bacilli Calmette-Guérin vaccine produced by deep-culture technique. Appl. Envir Microb., 34(5):495499, 1977.

7. Gheorghiu, M.; Lagrange, P.H.; Fillastre, C. The stability and immunogenicity of a dispersed-grown freeze-dried Pasteur BCG vaccine. J. Biol. Stand., 16:15-26, 1988.

8. Sakai, M.C.; Hiss, H. Influence of surface-active agent concentration on the spectrophotometric biomass estimation during submerged growth of Mycobacterium bovis. Braz. J. Chem. Eng., 14(3):299302, 1997.

9. Box, G.E.P.; Hunter, W.G.; Hunter J.S. Statistics for Experimenters. John Wiley \& Sons, New York, 1978, 653p.

10. Borzani, W.; Baralle, S.B.; Correction of results obtained in laboratory-scale studies of batch cultivation kinetics. Biotech. Bioeng., 25:3201-3206, 1983.

11. A.O.C.S. Method Ea 6-51. In: Official Methods and Recommended Practices of the American Oil Chemistry Society, AOCS, Illinois, 1987, p.6-51.

12. Lima, L.S. et al. Doseamento de Nitrogênio. In: Farmacopéia dos Estados Unidos do Brasil, Brazilian Health Ministry, Brasilia, 1959, p.960-967.

13. Kemmerer, G.; Hallett, L.T. Improved micro-Kjeldahl ammonia distillation apparatus. Ind. Eng. Chem., 19:1295-1296, 1927.

14. O.M.S. Revised Requirements for Dried BCG Vaccine. In: Vitro Assays of BCG Products. Org. Mond. Santé (Ser. Rapp. Techn.), Geneve, 638:3-18, 1979.

15. Difco manual. Dehydrated Culture Media and Reagents for Microbiology, 10. ed. Difco Laboratories, Detroit, 1985, p.1027.

16. Malucelli, M.I.C.; Niero, R.; Lucchiari, P.H.; Bacila, M. Evaluation of the polarographic technique for assay of the viability of freezedried BCG vaccine: I. The polarographic technique. Vaccine, 13(3):268-272, 1995.

17. Malucelli, M.I.C.; Niero, R.; Lucchiari, P.H.; Souza, M.D.C.; Bruzzo, D.; Alves, R.C.B.; Miguel, O.; Bacila, M. Evaluation of the polarographic technique for assay of the viability of freeze-dried BCG vaccine: II. Viability of the vaccine assessed by polarography, Warburg respirometry and colony counting. Vaccine, 13(3):273275, 1995.

18. Milinkovic, M.; Vlajinic, S. Relationship between oxygen consumption and colony count test. International Symposium on BCG Vaccine, Frankfurt, 1970, v.17, p.227-232.

19. Vancetto, M.D.C. Cultivo submerso do Mycobacterium bovis para a produção do BCG imunoterápico. 2003, 97p. Doctoral thesis presented to the "Programa de Pós-Graduação Interunidades em Biotecnologia USP/IPT/Instituto Butantan, São Paulo (Brazil).

20. Stover, C.K.; Cruz, V.F.; Fuerst, T.R.; Burlein, J.E.; Benson, L.A.; Bennett, L.T.; Bansal, G.P.; Young, J.F.; Lee, M.H.; Hatfull, G.F.; Snapper, S.B.; Barletta, R.G.; Jacobs, W.R.; Bloom, B.R. New use of BCG for recombinant vaccines. Nature, 351:456-460, 1991.

21. Lugosi, L. Analysis of variables of plasmid transformation of a bacterial vaccine: studies on recombinant BCG. Vaccine, 8(2):145149, 1990.

22. Hanson, M.S.; Lapcevich, C.V.; Haun, S.L. Process on development of the live BCG recombinant vaccine vehicle for combined vaccine delivery. Ann. New York Acad. Sciences, 754:214-221, 1995.

23. Fuerst, T.R.; Stover, C.K.; Cruz, V.F. Development of BCG as a live recombinant vector system: potential use as an HIV vaccine. Biotechnol. Ther., 2(1-2):159-178, 1991.

24. Uno-Furuta, S.; Matsuo, K.; Tamaki, S. et al. Immunization with recombinant Calmette-Guerin bacillus (BCG)-hepatitis C virus (HCV) elicits HCV-specific cytotoxic T lymphocytes in mice. Vaccine 21 (23):3149-3156, 2003.

25. Abdelhak, S.; Louzir, H.; Timm, J. et al. Recombinant BCG expressing the leishmania surface-antigen GP63 induces protective immunity against Leishmania major infection in Balb/C mice. Microbiology UK (141):1585-1592, 1995.

26. Varaldo, P.B.; Leite, L.C.; Dias, W.O.; Miyagi, E.N.; Torres, F.I.; Gebara, V.C.; Armoa, G.R.; Campos, A .S.; Matos, D.C.; Winter, N.; Gicquel, B.; Vilar, M.M.; McFadden, J.; Almeida, M.S.; Tendler, M.; McIntosh, D. Recombinant Mycobacterium bovis BCG expressing the Sm14 antigen of Schistosoma mansoni protects mice from cercarial challenge. Infect. Immun., 72(6):3336-3343, 2004.

27. Portaro, F.C.; Hayashi, M.A.; Arauz, L.J.; Palma, M.S.; Assakura, M.T.; Silva, C.L.; Camargo, A.C. The Mycobacterium leprae hsp65 displays proteolytic activity. Mutagenesis studies that the M. leprae hsp65 proteolytic activity is catalytically related to the HsIVU protease. Biochemistry, 41(23):7400-7406, 2002.

28. Dietrich, G.; Mollenkopf, H.J.; Weber, H.; Knapp, B.; Diehl, K.D.; Hess, J.; Blackkolb, F.; Bröker, M.; Kaufmann, S.H.E.; Hundt, E. Cultivation of Mycobacterium bovis BCG in bioreactors. J. Biotech., 96:259-270, 2002.

29. Zhang, J.; Greasham, R. Chemically defined media for commercial cultivations. App. Microb. Biotechnol., 51:407-421, 1999.

30. Brock, T.D.; Modigan, M.T.; Martinko, J.M.; Parker, J. Biology of Microorganisms., 7th ed., Prentice Hall, New Jersey, 1994, 909p. 